This is a self-archived version of an original article. This version may differ from the original in pagination and typographic details.

Author(s): Kauppi, Niilo; Madsen, Mikael Rask

Title: Non-elected Political Elites in the EU

Year: 2018

Version: Accepted version (Final draft)

Copyright: (C) The Author(s) 2018

Rights: In Copyright

Rights url: http://rightsstatements.org/page//nC/1.0/?language=en

Please cite the original version:

Kauppi, N., \& Madsen, M. R. (2018). Non-elected Political Elites in the EU. In H. Best, \& J. Higley (Eds.), Palgrave Handbook of Political Elites (pp. 381-397). Palgrave Macmillan.

https://doi.org/10.1057/978-1-137-51904-7_25 


\section{Non-elected political elites in EU}

Niilo Kauppi, University of Jyväskylä and Mikael Rask Madsen, University of Copenhagen*

\section{Introduction}

With globalization and Europeanization profound changes have taken place in the composition and structure of elites. Once solidly tied to the nation state, elites have, following processes of differentiation and specialization, become more transnational than ever before. Their development has been conditioned by the evolving relationship between international, transnational and national powers. This has meant that new elites have shaped supranational institutions like the European Court of Justice, the European Commission, the OECD (Organisation for Economic Co-operation and Development), and the World Bank to name a few. In the European context, key institutional players today include the European Commission, the European Ombudsman and the European Court of Justice (ECJ/CJEU) as aspiring representatives of the general European interest and the Council of ministers and member-states as representing national interests in the EU. Their relationship and changing interfaces are crucial when assessing the development of non-elected political elites as well as more generally the rise of an institutionalized and integrated Europe (Cohen, 2013). Since the 1950s a bifurcation has developed between, on the one hand, increasingly autonomous European and global-level policy networks revolving around European and global public policies (Slaughter, 2003) and relatively weak general, national public spaces confined to the nation state and its decision-making structures. This contradiction has prompted some to call for a postnational democracy (Habermas, 2015) and others to denounce the democratic deficit of the EU (European Union) (Follesdal and Hix, 2006, Kauppi, 2005), as well as other international organizations (Nye, 2001).

In this chapter, we focus on non-elected elites in the EU. We start with a brief presentation of some of the socio-political and legal conditions that enable in the EU the formation of non-elected political elites. We then discuss in more detail two key European institutions marked by non-elected elites, the ECJ and the institution of the European Ombudsman respectively. We conclude by raising some more points about non-elected political elites and their resources in transnational society.

\section{A fertile ground for non-elected political elites}

Many scholars consider the European Union as the most complex political system in history. This is mostly due to the scalar levels involved in its activities. These include the local and regional levels, the national level of the member states, the supranational level of the Union itself, and finally in many domains the global level. The complexity has also to do with the fact that the Union, and the European integration process, is constantly evolving. The competencies of the European Commission, which represents and acts in the name of the Union, have evolved. They are very uneven, but the Commission can be described as being, to paraphrase Max Weber, an expansive political organization (Weber, 1959). The key to understanding the political actions of both the EU

\footnotetext{
* Mikael Rask Madsen's research is funded by the Danish National Research Foundation Grant no. DNRF105 and conducted under the auspices of the Danish National Research Foundation's Centre of Excellence for International Courts.
} 
and the member-states is to see the relationship as being one of growing mutual dependency. Periods of rapid acceleration, like during the two Jacques Delors presidencies 1984-1989, 19891994, have been followed by periods of disorientation and chaos, like the present period. The process itself has a direction, but nobody is in a place to impose a singular masterplan. Some, but this is a minority, would like to see a federalized European superstate, yet most are happy with the unusual hybrid that exists at this moment. In terms of historical models the EU is a unique hybrid, a supranational bureaucracy that has political ambitions to represent European democracy. And in its surroundings an ever larger group of economists, lawyers and lobbyists are seeking to influence its direction and policies.

According to the literature what characterizes the actions of the European Union is technocratic politics, of European public policies without politics, of low politics in contrast to the high politics that involves major political leaders and decision-makers, that is, the traditional elected and executive political elites. Explaining this preeminence of non-elected elites requires going back in history. When World War II ended, the Americans began a massive aid program called Marshall Aid that aimed at rebuilding Europe. Institutions such as the future OECD were created for this purpose. On the basis of this American led experience the Europeans started building European institutions to manage recovery. In 1953, the Americans pulled out because of the Korean War and the Europeans were left on their own devices. Political leaders, ranging from social democrats to Christian Democrats, Liberals and Conservatives, shared the same diagnosis: the culprit for WWII was nationalism and the political extremism that went with it. Building supranational institutions was seen as the only way to avoid the mistakes that had led to the two world wars. But nationalism was still a powerful force, limiting the possibility of establishing genuine supranational political institutions. The solution to the dilemma was to create non-political institutions that were not on the radar of politicians, the media and the public. This opened the door for the development of a slew of more technocratic elites that were not elected but nevertheless played important roles in subsequent developments.

To satisfy French imperial ambitions French bureaucratic concepts and practices were transferred from the national level to the European level. Commissaire, Haute autorité, Assemblée commune and others were institutional concepts that described a new reality that was not reducible to national politics and concepts such as government and parliament. In this process a key role was played by Jean Monnet, a French civil servant who had held important positions in the League of Nations and had been the head of the French Commissariat général au plan, the central planning agency of the French economy. His idea was that a small, elite administration would spearhead European integration. Integration would advance by the force of its own logic, incrementally, by small steps and spillovers from one domain to another, quasi-automatically as neofunctionalist theory soon predicted.

The dramatis personae themselves in their memoirs as well as scholars have presented this Jean Monnet method of European integration as being the dominant method since the beginning of European integration. It is more complicated than this, however. National political leaders have also played a crucial, but concealed role. They were crucial in the sense that they gave their backing to this method of integration. Paradoxically the EUs non-political politics has been highly political since the beginning. For some time a consensus prevailed among national political elites that this apolitical mode of integration was the only realistic one. The French president Charles de Gaulle however shattered this consensus in 1966. While developments since the 1950s had gone toward a supranational Europe, in his vision Europe should have continued to be a federation of nation states. 
In 1966 France boycotted for seven months the activities of European institutions. This way de Gaulle revealed the double game: the political will of national political leaders made possible incremental bureaucratic integration, and without this backing European integration would not advance. This also revealed the mutual dependency of national and supranational elites as a key to understanding the, often contradictory, logics of European integration as well as the ways in which non-elected political elites have gained power in Europe. De Gaulle confirmed that European institutions were nothing without the political legitimacy of national leaders.

Through his actions de Gaulle underlined an important tension between on the one hand input legitimacy and on the other hand output legitimacy, a tension that has been constant in the history of European integration. Input legitimacy refers to the relationship citizens have with political institutions through elections and civil society, and involves issues such as trust, political identity, emotional attachment, and so on. Traditional elected political elites hold a monopoly over this resource. Output legitimacy refers to what the political system produces, for instance services of various kinds, education, health care, transports etc. For de Gaulle national leaders had a monopoly on both fronts. And the role of supranational elites in providing any of these was minimal in his view. This was probably true in 1966. But today the situation is different. As an expansive political organization the EU has been growing from an initial role as a supranational secretariat or bureaucracy into a real political organization, challenging the member-states' monopoly over input legitimacy. Although the European Parliament is now directly elected and has been given more powers in the Lisbon treaty, the political attachment of Europeans to the EU continues to be low, as voting turnout to the EP elections shows. Input legitimacy is still largely a monopoly of national politics while the EU and member states share output legitimacy.

The EU has gradually become the provider of a wide set of outputs that range today from a common currency to representation of the EU in world trade, a complicated legal system and the management of the EUs external borders for instance. These developments would not have been possible without the actions of a variety of non-elected political elites that are specialized in the issues in question. There are however important difference between national public policies and European public policies that need to be pointed out. The first one is that the sums of money involved in European public policies are smaller than those in many member states. The yearly budget of the EU is around 140 billion euros, about the size of the national budget of a small member-state, Finland. While this seriously hampers the development of the European bureaucracy it nevertheless has provided an opportunity for new transnational elites to develop. The second one is that the geographical and social distance is greater between those who formulate policies and those who execute them. This means that intermediaries are necessary to fill this void, to transmit to the national and regional level what is happening at the EU level. And third, the domains of action of the EU are narrower than those of national governments.

The EU can act only in those domains where it has competencies but not in others. ${ }^{i}$ This conditions the development of elite social groups. Those attached to European policies are able to develop expertise in areas that are relevant for these policies. These can have to do with legal regulations, or with knowledge relevant to financial integration, for instance. Newer areas include higher education, where the European Commission has been investing heavily since the beginning of the 2000s. What kinds of non-elected groups have developed that play an important role in European politics? European public policies have until now favored capital at the expense of work, urban consumers at the expense of rural producers, and peripheries at the expense of centers. The first 
dimension is exemplified by the creation of a free zone for the movements of goods, capital and workforce.

\section{Transnational elites}

Compared to the 1950s the current political landscape in Europe is much more complicated, with more institutions and actors of various kinds involved in European public policies that have proliferated. Processes of autonomization and specialization of social groups have taken place, enabling some to become professionals in European issues. These include politicians, bureaucrats, lawyers, activists, journalists, and so on. This autonomization and specialization has involved the linking of the evolving supranational level to national, regional and local levels. European experts who have access to specific European resources will be found at all levels of the system, from the smallest hamlet in the remotest part of the continent to the EU 'capitals' of Brussels and Luxembourg, and to a lesser extent Strasbourg. Today there are politicians who specialize in European issues. This type of Europaberufspolitiker to paraphrase Weber did not exist 20 years ago. We can say that a differentiation of elites, public policies and public spaces have taken place. New transnational elites operate in European institutions and actively participate in the shaping of supranational public policies (Kauppi and Madsen, 2013, 2016).

A variety of elites revolve around European institutions that consist of around 6.000 policymaking positions and around 20.000 translators, that form together the bulk of the workforce that is called the EU administration. Thousands of trainees, national experts that are in temporary posts, and representatives of member-states, diplomats mostly, supplement these 6.000 positions. Those with permanent positions in the Brussels bureaucracy form the vanguard of European integration, working full time for the Union. With the increase in the supranational outputs a variety of other types of elites have however formed. These include lawyers, journalists, academics, lobbyists and various representatives of interests. According to some estimates various interest groups employ around 10.000 persons in Brussels today. These range from consultants to law offices and professional groups of various kinds. European institutions have consulted these since the beginning of European integration. The main reasons for this dependency are the small size and limited resources of the European administration and the expansion of its outputs. With time some of these relationships have become more formalized. Various expert groups and committees exist today and the Commission consults with nearly a 1000 ad hoc groups.

In terms of the permanent, key personnel in European institutions European Commission officials play a key role in supranational integration. Commissioners are mostly male, over 50, with considerable legislative and executive experience in their home country. Their profiles correspond to ministerial profiles in their home countries (Egenberg, 2006). Some research shows that Commission managers favor deeper European integration regardless of their national origin or organizational experience (Ellinas and Suleiman, 2012, see also Egenberg, 2006). They see as their main mission the integration of Europe. Other research is more nuanced (Hooghe, 2012). According to Liesbet Hooghe, Commission officials can be divided into three groups in terms of their vision of European integration. According to her survey 36.6 per cent are in favor of a supranational Europe with the Commission acting as its government. Hooghe contrasts these supranationalists with statecentric officials, 13.3. per cent of the respondents, who see the European Union as essentially an intergovernmental organization. To these types Hooghe adds an institutional pragmatist one that is in favor of neither, which composes 29.3 per cent of the population, and an ambivalent one that cannot be included in any of the categories ( 21 per cent). These types cover well the different 
perceptions officials have of their role and of the development of the EU. IN terms of political ideology the Commission is broadly representative of European societies, at least on traditional economic left/right issues. Not surprisingly social DGs (directorates-general) significantly more social-democratic than DGs handling market integration. Officials from new member states are more market-liberal than their 'western' colleagues. Concerning the common opinion that European officials just want to increase their own power, Hooghe finds that Commission officials want more EU authority, but their desire to centralize is selective and measured. According to Hooghe 'It seems driven by functional imperatives - centralization where scale economies can be reaped - and by values and ideology rather than by a generalized preference for maximal Commission power' (2012). Other research (Michel, 2013) shows that the sociological profiles of European officials and interest representatives and lobbyists are similar: they have gone through the same schools and have similar experience prior to integrating the Commission or interest representation organizations.

Until the Single Act in 1986 European interest representation consisted of activities that targeted mostly the Council of Ministers, that is, the representatives of member-states. Following a deepening and expansion in the integration process, interest representatives started targeting the Commission. And today with the increase in the powers of the European Parliament they have increasingly shifted their attention to the parliament. The paradigm of interest representation evolved from a corporatist paradigm, or a government paradigm, that favored a few relatively large organizations, a limited scope of public policies and elite groups, into a pluralist or governance paradigm with a greater variety of policies and actors. This has involved an increase in the number of consultancies as well as a greater role of markets in policy making. With the increased powers of the European Parliament a further shift has occurred, from non-elected elites to directly elected supranational political elites. These play a more important role in the European policy process, a novelty. However, with decentralization and the principle of subsidiarity (that is that outputs have to be produced as close to the citizens as possible) national and regional actors play a key role in European public policies, further shaping elite group formation.

Most of the organizations that seek to influence European are composed of one or a few individuals (Courty and Devin, 2005). Three kinds of organizations can be distinguished:

1) Private organizations. These represent the business world, and the great majority of so called Eurogroups, that is European level interest groups. The most represented sectors are the chemical industry and firms linked with the environment. Highly federated groups like BUSINESSEUROPE, the European association of industries and employers, and the European Round Table of Industrialists (ERT) are highly influential. High-level executives with considerable social and economic capital such as the CEOs of Philips and Nestlé have manned these. The European representative of the workers, the European trade union confederation (ETUC), is composed of 85 national trade union confederations.

2) NGOs and associations. These range from Friends of the Earth and Greenpeace to representatives of German automobile constructors. For organizations like Greenpeace or Amnesty International the Brussels offices are policy offices of global organizations. The EU directly funds over half of public interest groups. Some even act as agents of the EU via various development projects both in Europe and beyond Europe. The European Citizens Action Service for instance has functioned as the EU's monitoring instance in the area of the free movement of people. A coproduction of supranational bureaucratic elites and supranational civil society elites can be observed. 
3) Regional representations. These include for instance the representation of the Land of Bavaria, which is larger and better funded that many EU member state representations.

In general non-elected political elites develop where funds are available, and interest representation evolves where there are supranational policies that can be influenced. Three structural factors of European decision-making influence directly the actions of these new elites.

1) National tensions and differences condition their development and influence. For instance the promoters of environmental protection can be faced with national policies that are hostile to them, especially in member states that are net recipients of EU money. Multinational actors have an interest in putting together their resources and trying to influence the Commission, but some actors like representatives of trade unions are handicapped by the existence of very different national traditions. French trade unions like the CGT, Confédération générale du travail, have traditions that are quite different to for instance large Swedish trade unions like the LO, Landsorganisationen. The CGT has a tradition of direct action, a strategy of the street, with a strong hold in certain sectors like railroad workers. In France the level of union membership is very low compared to Sweden or Germany. French trade union elites are not used to concerted action or common action with unions from other countries. In this way national traditions hamper the development of a unified trade union elite at the European level. The same goes for political parties. European political parties are at the moment weakly developed and resemble more an assemblage of national parties.

2) The competencies of the Union. The more the Union's capacity to operate is important, the more you will find European level pressure groups and elite formation. For instance in the area of primary or secondary education there are very few European level groupings. In contrast, in higher education there is today more than before, mainly because HE has been framed since the 2000s as a key element in the knowledge economy and the competitive edge of European economies. For this reason the Commission plays an important role in coordinating this area and associations such as those representing European universities are actively shaping Union policies. In order to succeed these elites have adopted a language that is close to the language used by the Commission and other EU institutions. And the aims of the action have to be concordant or in harmony with the aims of the EU as formulated by the EU. Higher education governance in the EU has been developed by a set of high-powered university professors in specific research centers such as the CHEPS (Center for Higher Education Policy Studies) at the University of Twente in the Netherlands. Individuals like Frans van der Vught was a member of the Group of Societal Policy Analysis (GSPA) of the European Commission (under the leadership of former European Commission President Barroso) and he also sits of the Executive Board of the European University Association (EUA). His institute has been instrumental in the creation of the EU's U -multirank tool for the evaluation of higher education institutions, a tool that is poised to become a competitor to dominant rankings such as the Shanghai ranking and the THE (Times Higher Education) ranking of world universities.

3) Decision making modalities. The default decision-making modality in the EU is the Community method, where the European Commission, together with the European Parliament and the Court of Justice as developer of European law, plays a key role as the initiator of policies, controller of the implementation of these policies and of the Union's agenda. When competencies are shared between the EU and the member-states such as is the case with most European public policies (environmental protection, consumer 
protection, mergers, transports, development aid etc.), the interaction between the two will be determinant. In a second decision-making method, the intergovernmental method, key players will be national political leaders and civil servants. Policies involved include fiscal policies for instance. And a third, more recent decision-making procedure is the Open method of coordination (OMC) that the Commission uses increasingly in areas like social policy and higher education, areas where it does not have a priori any power. In the intergovernmental and OMC modalities few incentives exist to develop European level power strategies. Today the general development is toward more flexible coordination methods like the OMC. The OMC gives European institutions a slightly ambiguous role as an arena where new approaches can be developed and coalitions formed to solve policy problems, with the active participation of non-elected political elites. Various transnational networks of elites play a key role in this process, reinforcing the technocratic and transnational dimension in EU politics. The OMC has introduced into European public policies a whole set of concepts and techniques from new public management that have changed the way public policies are formulated. These include benchmarking, best practices and so on. The strategy of Lisbon, that is the making of the EU into the most competitive economy in the world, is a good example of this kind of policy coordination. The OMC has been the Commission's power strategy to acquire resources in areas where it does not have any competencies and which are in other words the domain of the member-states. In these an expansive European Commission has taken the role of general coordination.

Non-elected political elites have clearly transformed with the evolution of the Commission and its European public policies. These have been technocratically determined, often business led, a key mechanism being the revolving doors between the Commission and business/finance, which has enabled the circulation of elites from supranational bureaucracy to international business. As for European civil society organizations, the EU often finances them. This is especially the case with smaller organizations and public interest groups. In exchange, they provide the Commission with the input legitimacy and information it craves (coproduction of policies and stakeholders). Many like the CNPSA (Confederation of national political science organizations) have a formal existence as European level organizations. The small size of the supranational administration leads to a structural dependency on lobbies and other non-elected actors to provide information and expertise. A constant concern has been the desire of supranational elites to regulate their legal environment. And to increase their input legitimacy by promoting values such as democracy and equality. At the receiving end, European institutions have welcomed such input legitimacy but also sought to institutionalize new non-elected elites to ensure the balance between broader legitimacy and the output of the EU.

In order to explore this key issue which is at the heart of many debates on the EU, we will turn to two particular European institutional elites, the European Ombudsman and the Court of Justice of the EU (CJEU). The European Ombudsman is illustrative of an institutions that has been established as almost out of simply necessity for the development of the EU as a legitimized and somewhat more any democratic regime, whilst the ECJ/CJEU has since the 1960s functioned as a legal motor of European integration, often providing key input in times of political inertia. Moreover, it has almost single-handedly produced a catalogue of rights that only later were formally codified in the European Charter of Fundamental Rights (2000). 


\section{The Ombudsman}

The transplantation of the Ombudsman from national contexts to the European Union has been all but straightforward. For one, the Ombudsman has taken different forms in the national contexts where it has been adopted. In Europe, there are two Ombudsman traditions. In the Nordic countries, the Ombudsman institution is the legal overseer of government and executive. In this conception the Ombudsman, in practice a group of senior lawyers, investigates citizens' complaints and passes a public judgement on the legality of the actions of public administration in the case concerned. There are no formal sanctions but the public judgment carries its own efficiency. In contrast, in many central and Southern-European countries the Ombudsman is a mediator, seeking to solve disputes between different parties in a social conflict.

Adopted in the Maastricht Treaty of 1992, it was in 1995 that the European Parliament appointed the first European Ombudsman, the Finnish lawyer and politician Jacob Söderman. The successful adoption of the European Ombudsman institution was largely a question of good timing. The European Parliament had already discussed the creation of the Ombudsman in 1979, without effect. This political transplantation was the outcome of several favourable developments between 1979 and 1992. In the early 1990s, the question of human rights was high on the agenda in the EU (Madsen, 2013). Human rights became one of the key domains of the Ombudsman, and the increased attention paid to them also legitimized creating the Ombudsman institution at the national level. By the beginning of the 1990s, all EU member states had adopted the Ombudsman institution on a national level. This led to an increased awareness and political acceptance of the institution, which was not the case in 1979. Also, EU law had already become an independent legal system, which spoke in favour of adopting a European control system (Biering, 2005).

A possible source of complications for the adoption of the Ombudsman institution could have been the fact that it did not follow the main traditions of EU law, but was instead of Scandinavian origin. However, some scholars argue that this "foreign origin" might have in fact eased its adoption since it did not pay homage to established divisions or disputes within EU law. Also the resistance of other EU institutions was modest since these institutions seldom dealt with European citizens, the "clients" of the Ombudsman. The strongest opponent of the initiative was the European Parliament's Committee on Petitions, which saw the Ombudsman as its prospective rival (Biering, 2005). At the same time, the increase in the powers of the European Parliament since the 1970s had transformed the inter-institutional dynamics between key European institutions, the Parliament, the Council, and the Commission. The Ombudsman had found an ally and competitor in the Parliament, as both tapped on the development of a more democratic citizens' Europe.

The breakthrough of the Ombudsman took place at a time when questions of democratisation and transparency were high on the EU agenda (Cini, 2007, Héritier, 2003, Erkkilä, 2012). Both the Santer (1995-1999) and Prodi (1999-2004) Commissions tried to reform European institutions following these principles. Transparency, or public access to the information held by the institutions, was officially acknowledged for the first time in the Maastricht Treaty in 1992. Apart from the mounting criticism towards the opaque decision-making procedures in the Council of Ministers, general concerns about the state of democracy in the EU and its implications to its legitimacy in the member states were vocal at this time.

The issue of transparency was first debated already in 1979. The European Parliament used transparency as an argument to increase its powers. In nation-states, parliamentary institutions have been historically formed to allow for political inclusion, representation, and public debate. 
Analogously, the European Parliament argued that an increase in its power would bring more openness to the EU (Gonzalez, 2005). The resolution to create the Ombudsman institution was reached in the Treaty on the EU after a Spanish initiative based on a Danish proposalii. Active on this issue both in 1979 and 1992, Denmark insisted that the European Ombudsman should not be a politician. The appointments of Jacob Söderman as the first European Ombudsman, P. Nikiforos Diamandouros as his successor in 2005 and Emily O'Reilly to succeed to Diamandouros in 2013 were in line with the Danish proposal since all had acted as ombudsmen in their own countries (Biering, 2005, p. 45). That being said, in Finland Jacob Söderman is mostly known as a SocialDemocrat politician, having had a significant political career as an Member of Parliament (19721983), Minister of Justice (1971), Minister of Social Affairs and Health (1982) and County Governor (1982-1989) before becoming Finnish Parliamentary Ombudsman (1989-1995). The fact that this political past never became an issue when Söderman was acting as European Ombudsman demonstrates his ability to act coherently in different roles, both as a politician and a bureaucrat, and to effectively use the various resources at his disposal. By systematically emphasizing its nonpolitical and extra-judicial nature, Söderman succeeded in implanting the Ombudsman into the European institutional field.

Defining the discourse of "good governance" and "maladministration" became the key challenge for the European Ombudsman in the early years (Söderman, 2005). The main sources of grievances had been the lack of openness in terms of access to documents and information, and staff matters linked with recruitment through open competitions (concours). The Ombudsman institution basically had to adapt itself to an evolving institutional environment. This was especially clear in complaints related to contractual matters. National ombudsmen did not deal with these complaints because they were considered as being commercial disputes (Söderman, 2005). In the European context, they have been one of the staples of the Ombudsman.

Since 1995, the caseload of Ombudsman has been on a steady rise. The years 2004 and 2005 marked a clear increase in complaints. This was a result of EU enlargement as ten new member states entered the Union. Although the cases, mainly consisting of complaints, have increased from 298 in 1995 to 4416 in 2005, the amount of yearly decisions has been steady and under 400 . A clear majority of the complaints have not been within the mandate of the Ombudsman, i.e. they have been addressed to the wrong institution. This discrepancy between the complaints and the resolutions indicates that there is little public knowledge concerning the Ombudsman's mandate and functions. In fact, in 2005 , over 70 per cent of complaints did not fall within the mandate of the Ombudsman. However, starting from 2007, there has been a steady decline in the number of the cases. This seems to indicate normalization after the rapid increase following EU enlargement. Interestingly, the complaints have sunken roughly to the level of 2003. Also the number of cases within the Ombudsman's mandate has slightly increased, though there is no major difference in sight. Nevertheless, the statistics indicate that the institution has channelled general social pressure that is not linked to its mandate. Moreover, the European Ombudsman seems to be finding its standard level of operation in terms of complaints.

In the first years, the Ombudsman launched several own-initiative inquiries on various issues linked with maladministration. Through these inquiries the Ombudsman succeeded in engaging the other institutions, especially the Commission and Parliament, in reforms related to good administration, transparency, and access to documents. In this sense, Söderman as the first Ombudsman acted as an independent entrepreneur who had to carve for the institution a sphere of action and influence. 
In the discussions prior to the creation of the European Ombudsman's office, some European Parliamentarians voiced fears of the Ombudsman becoming a political tool of Parliament, to which it was to have financial ties in terms of budget, rather than an independent institution. From 1995 to 2000, the European Parliament decided on the budget of the European Ombudsman based on an estimate made by the Ombudsman bureau. The Parliament also provided some technical services. In December 1999, the Council agreed to grant the Ombudsman a budget of its own. Starting from January 2000, the Ombudsman's budget has been an independent section of the European Union's budget. The appropriations for 1997 were 2.6 million ECU and in 2005 the annual expenditure had more than doubled to 6.3 million euros. Initially, the staff of the Ombudsman bureau was hired on temporary basis. Since 2000, a gradual transition towards permanent posts has taken place. The bureau was also separated into different departments. These developments form important turning points in the institutionalization of the European Ombudsman, which counts today a staff of 83 persons.

Such extra-judicial institutions of public accountability, to a certain extent, also need turning points in order to keep up their legitimacy in the eyes of the public. Conflicts between the Ombudsman and other European institutions can give institutions of public accountability the publicity that they usually lack. Conflicts can become defining moments, when the political function of an institution crystallises itself both to the representatives of other institutions and to the wider public. In 1999, Romano Prodi was elected President of the European Commission after the resignation of Jacques Santer's Commission. A social demand for charismatic political action existed. Prodi's ambitious statement on the objectives of the Commission indicated that the new Commission wanted to become a European political government. One of Prodi's points had to do with new European governance. The White Paper on European Governance was to play a politically equivalent status to the similar documents on economic competitiveness and employment. The Ombudsman played a key role in this broader dynamic.

In the post-Lisbon Treaty era, the European Ombudsman has come to redefine fundamental rights. The Lisbon Treaty brought the Charter of Fundamental Rights of the EU into force, stating that any citizen of the Union (and any natural or legal person) has the right to refer to the Ombudsman of the Union in cases of maladministration. Also citizens' right to access European Parliament, Council and Commission documents was added to the Charter of Fundamental Rights of the European Union. It is important to differentiate fundamental rights from human rights. However, the entry of maladministration into the charter will shape the understanding of "rights" in the European Union.

\section{The Court of Justice of the EU}

French sociologist Antoine Vauchez recently published a newspaper article with the provocative title: "The New President has arrived, and it is a judge" (Vauchez, 2015). Analyzing the change of presidency of the Court of Justice of the EU (CJEU), Vauchez sought to point to the fact that the key institutions of the EU are those of only quasi-elected nature, namely the CJEU alongside the Central Bank and, of course, the Commission. He has further developed this argument in small succinct book that argues that to democratize the EU, one needs to look not at the institutions of formal power like the Parliament but those of real power like the Court, Bank and Commission (Vauchez, 2014). This raises the question of how the CJEU, and before that the European Court of Justice (ECJ), has managed to come to the forefront of European politics and integration. Prior to the establishment of the EU, no European countries had a legal-political culture of gouvernement des juges (Madsen and Thornhill, 2014). Rather, the ideology was the opposite, namely that the judges were only la bouche de la loi - the mouthpiece of the law. In fact, the term gouvernement 
des juges stems from a critique of the US Supreme Court in its early jurisprudence, notably Marbury v. Madison (1803), and articulated by French legal comparativist Édouard Lambert in the beginning of the $20^{\text {th }}$ century.

Like in the case of the Ombudsman, the rise of the ECJ/CJEU as a real force in European integration is in part due to timing, in this case the Court filling the vacuum in European integration created by the lack of initiative at the political level in the 1960s as described above. It was precisely in 1963 and 1964 that the ECJ in the decisions of Van Gend en Loos and Costa v. ENEL established the doctrine of the direct effect and supremacy of European law, thereby forging the fundamentals of a supranational European legal order from which the member states could not escape through non-compliance (Weiler, 1991). The two decisions have in much literature been turned into the veritable 'Big Bang' of European law and remain to this day 'founding myth' of European law (Vauchez, 2012). Interestingly, from 1950 until these landmark decisions the community legal order was anything but the self-sustained supranational legal order of today (Boerger-De Smedt, 2008).

Recent scholarship has suggested that the two ECJ landmark decisions were hardly the product of the activism of the Court alone. Instead it was the product of a much broader mobilisation around supranational European law sponsored by a host of networks and institutions, including in particular the EC institutions themselves and notably the Legal Service of the Commission (cf. Alter, 2009, p. 63-91, Vauchez, 2010). Both Van Gend en Loos and Costa v. ENEL were issued at a point in European history where the question of European integration once again was heavily debated, partly due to the changing French position on Europe under de Gaulle. While many studies have equalled this with a general decline in the support for European integration, more recent research tend to argue that the situation is perhaps better captured by emphasizing that much focus was on the massive undertaking of developing a Common Agricultural Policy (CAP) which was to become the single biggest and most controversial item on the EC budget (Knudsen, 2009). Moreover, while the rhetoric of particularly France under de Gaulle exhibited some ambiguities with respect to European integration, it does not thereby follow that France was 'eurosceptic' or simply bad Europeans (Weiler, 1991, Ludlow, 2006). As Andrew Moravcsik famously, but equally controversially, has argued, French grains, de Gaulleian grandeur and European integration were not by definition mutually exclusive (Moravcsik, 2000, p. 3-43).

In practice, the decisions did not have an immediate impact and it is only subsequently they have gained the status of seminal moments of European integration. As a matter of fact, the legal systems of key member states actually opposed or ignored these decisions. Thereby, the impact of these new principles of European law was in practice delayed by at least a decade in France as well as Germany. In practice, the ECJ was basically far from having established itself as the supreme voice of European law. That would only happen subsequently, in part as a result of the significant enlargement of the domain of the EC/EU.

In his seminal article 'The Transformation of Europe', Joseph Weiler divides the development of EC law into three major phases: 1) a foundational period (1958-mid 70s) developing the jurisprudence on direct effect, supremacy, implied powers and human rights, 2) a period of mutation of competences 1973-mid 80s, and 3) contemporary EC law beginning with the Single European Act (Weiler, 1991, p. 2403-83). Since then further key moments have occurred with the Maastricht Treaty (1992) and the adoption of the European Charter of Fundamental Rights (2000) and more recently the Lisbon Treaty (2007), renamed the Treaty on the Functioning of the 
European Union (TFEU). Interestingly, in almost all instances the Court has managed to maintain its key role as guardian of an ever-closer Union. Only slight exception was the Maastricht Treaty where the Court was left out of two of the three pillars, albeit the two smallest pillars (Common Foreign and Security Policy (CFSP) and Police and Judicial Co-operation in Criminal Matters (PJCC)). Since then the Court has gradually bounced back.

Overall, the CJEU has a formidable power in EU affairs and a power that is far greater than any of its national homologues. This has also meant that the CJEU has spurred the development of a particular legal interest in European affairs, a form of legalized politics that is generally foreign to European legal-political culture marked by the supremacy of parliament. However the lobbying of law and the legal representation of private interests is largely taking place outside the realm of formal representative politics. In this realm, legal expertise tends to matter far more than democratic representativeness. This is not entirely taking place outside of formal politics but it is neither entirely controlled by formal politics.

\section{Conclusions}

Following processes of differentiation and specialization, elites become more transnational than before. In the case of the EU non-elected political elites such as legal elites and institutions analyzed in this chapter have played a considerable political role in the forging of supranational public policies and their output legitimacy. These are of course very particular and institutional nonelected elites that are part of the broader political regime of the EU. These elites have a legal background and combine national and supranational careers. But as suggested in the case of the CJEU such institutions produce a kind of alternative political arena to that of formal politics of elected elites. And they further spur the emergence of new forms of interest representation that seek to exploit these channels of influence. In a nutshell the EU political regime is a mismatch of formal political procedures exercised by elected or quasi-elected elites and a forest of other elites, both the institutional ones like the Ombudsman and the Court and the many other transnational power elites (Kauppi and Madsen, 2013) seeking to use all available platforms. 


\section{Bibliography}

Alter, K. (2009) The European Court's Political Power. Selected Essay. Oxford: Oxford University Press.

Biering, P. (2005) The Danish Proposal to the Intergovernmental Conference on Political Union. In The European Ombudsman: Origins, Establishment, Evolution. Luxembourg: Office for Official Publications of the European Communities.

Boerger-De Smedt, A. (2008) La Cour de Justice dans les négociations du traité de Paris instituant la CECA. Journal of European Integration History. 14. p. 7-33.

Cini, M. (2007) From Integration to Integrity: Administrative Ethics and Reform in the European Commission. Manchester: Manchester University Press.

Courty, G. and Devin, G. (2005) La construction européenne. Paris: La Découverte.

Cohen, A. (2013) The Genesis of Europe: Competing Elites and the Emergence of a European Field of Power. In Kauppi, N. and Madsen, M.R. (eds.): Transnational Power Elites: The New Professionals of Governance, Law and Security. Abingdon: Routledge.

Egenberg, M. (2006) Executive Politics as Usual: Role Behaviour and Conflict Dimensions in the College of European Commissioners. Journal of European Public Policy. 13. p. 1-15.

Ellinas, A. A. and Suleiman, E.N. (2012) The European Commission and Bureaucratic Autonomy. Cambridge: Cambridge University Press.

Erkkilä, T. (2012) Government Transparency: Impacts and Unintended Consequences. Basingstoke: Palgrave.

Follesdal, A., and Hix, S. (2006) Why There is a Democratic Deficit in the EU: A Response to Majone and Moravcsik. Journal of Common Market Studies. 44. p. 533-562.

González ,C.M. (2005) The Spanish Proposal to the Intergovernmental Conference on Political Union, in The European Ombudsman: Origins, Establishment, Evolution. Luxembourg: Office for Official Publications of the European Communities.

Habermas, J. (2015) The Lure of Technocracy. Cambridge: Polity.

Héritier, A. (2003) Composite Democracy in Europe: The Role of Transparency and Access to Information. Journal of European Public Policy. 10.

Hooghe, L. (2012) The European Commission in the $21^{\text {st }}$ Century. Core Beliefs on EU Governance. KFG Working Paper 38.

Kauppi, N. (2005) Democracy, Social Resources and Political Power in the European Union. Manchester: Manchester University Press.

Kauppi, N, and Madsen, M.R. (2013) 'Transnational Power Elites: The New Professionals of Governance, Law and Security.' Kauppi, N. and Madsen, M.R. (eds.): Transnational Power Elites: The New Professionals of Governance, Law and Security. Abingdon: Routledge, p. 1-16.

Kauppi, N, and Madsen, M.R. (2016) Global Elites. In Handbook of International Political Sociology. In Guillaume, X., Bilgin, P. and Salter, M.B. (eds.). Abingdon: Routledge.

Knudsen, A-C. L. (2009) Farmers on Welfare: The Making of Europe's Common Agricultural Policy. Ithaca: Cornell University Press. 
Lodge, J. (2003) Transparency and EU Governance: Balancing Openness with Security. Journal of Contemporary European Studies. 11.

Ludlow, P. (2006) The European Community and the Crises of the 1960s: Negotiating the Gaullist Challenge. Abingdon: Routledge.

Madsen, M.R. (2013) The Power of Legal Knowledge in the Reform of Fundamental Law: The Case of the European Charter of Fundamental Rights. In Vanchez, A. and Witte, B. de (eds.): The European Legal Field. Oxford: Hart Publishing. p. 197-219

Madsen, M.R., and Thornhill, C. (eds.) (2014) Law and the Formation of Modern Europe: Perspectives from the Historical Sociology of Law. Cambridge: Cambridge University Press.

Madsen, M.R. and Christensen, J. (2015) Global Actors. In Oxford Research Encyclopedia of Politics. http://politics.oxfordre.com/

Meyer, J. (2010) World Society, Institutional Theories, and the Actor. Annual Review of Sociology. 36. p. 1-20.

Michel, H. (2013) EU Lobbying and the European Transparency Initiative: A Sociological Approach to Interest Groups. In Kauppi, N. (ed). A Political Sociology of Transnational Europe. Colchester: ECPR Press. p. 53-78.

Moravcsik, A. (2000) De Gaulle between Grain and Grandeur: The Economic Origins of French EC Policy, 1958-1970. Journal of Cold War Studies. 2. p. 3-43.

Nye, J. (2001) Globalization's Democratic Deficit: How to Make International Institutions More Accountable. Foreign Affairs. 80. p. 2-6.

Page, E.C. (1997) People Who Run Europe. Oxford: Clarendon Press.

Söderman, J. (2005) The Early Years of the European Ombudsman, in The European Ombudsman: Origins, Establishment, Evolution. Luxembourg: Office for Official Publications of the European Communities. p. 83-105.

Slaughter, A-M. (2003) A Global Community of Courts. Harvard International Law Review. 44. p. 191-219.

Vauchez, A. (2010) The Transnational Politics of Judicialization. Van Gend en Loos and the Making of EU Polity. European Law Journal. 16. p. 1-28.

Vauchez, A. (2012) Keeping the Dream Alive: The European Court of Justice and the Transnational Fabric of Integrationist Jurisprudence. European Political Science Review. 4. p. 51-71. doi: doi:10.1017/S1755773911000105.

Vauchez, A. (2014) Démocratiser l'Europe. Paris: Seuil.

Vauchez, A. (2015) Le nouveau président de l'Union est arrivé et c'est un juge ! Libération, 9. October.

Weber, M. (1959) From Max Weber. Edited by Gunther Roth and C. Wright Mills. Berkeley: University of California Press.

Weiler, J. H. H. (1991) The Transformation of Europe. The Yale Law Journal. 100. p. 2403-2483. 
